Janusz Stankiewicz

University of Biatystok

\title{
MULTIANNUAL FINANCIAL PLANNING OF THE STATE IN POLAND COMPARED WITH SELECTED EUROPEAN COUNTRIES ${ }^{1}$
}

\section{General premises of introducing multi-annual financial planning}

Creating new currency by the Maastricht Treaty and transferring the monetary policy of the states participating in the Economic and Monetary Union onto the community level seems, from today's perspective, the most significant decision of an enormous impact on the further process of European integration. This thesis may be posited not only because it meant a practical implementation of the concept of monetary cooperation of European states which had earlier been formulated in the Treaty Establishing the European Economic Community, almost simultaneously with the breaking down of the monetary system established in Bretton Woods. Due to this, the economic crisis of the late first decade of the new millennium, unprecedented over the last dozens of years, could be opposed by the potential which considerably exceeded individual financial capacities of even the richest states.

The Maastricht Treaty established economic indicators which should be fulfilled by the state aspiring to participation in the Union. These indicators, also defined as Maastricht criteria, were subsequently reflected in the Treaty of Lizbon, which came to force in 2009, as well as in Protocol No. 13 determining the criteria of convergence. They refer to the condition of the state in the areas of monetary policy and budgetary policy. It is impossible, however, to omit the fact that, according to the official statistics of the European Central Bank, the total public debt of all euro

1 This Article was prepared within the framework of the project financed by the National Science Centre granted on the basis of decision no. DEC-2011/01/B/HS5/03357. 
zone states at the moment of introducing the currency into cash turnover ${ }^{2}$ amounted to $69.2 \%$ of GDP; thus, exceeding significantly the standards established.

It is also important to note that as early as the very beginning of the euro zone a connection between the undisturbed implementation of the economic and social goals and a good shape of public finances of the member states manifested in a lasting budgetary balance. It was taken into consideration that the European potential would be strong by the potential of the member states. It was noticed that troubles of a member state in balancing public expenses and weakening this state's potential means troubles of the community. Their consequences will be reflected both in the form of reducing such a state's payments to the European budget as well expecting aid in the form of financial support on the part of the community in order to lead the situation of this state to a relative balance of public finances.

While the introduction of common currency meant transferring monetary policy from a national level to the EU level, which resulted in strengthening the potential, which could be used against the effects of the economic breakdown caused by the economic crisis, the sphere of the state budgetary policy on this stage of integration was maintained at the discretion of national authorities, remaining in the conviction of full rationality of their actions. It is also important to underscore that with the simultaneous lack of precise standards of accountancy and financial reporting, requirements for conducting budgetary policy was formed quite generally. On the other hand, at that time European authorities did not have effective instruments of affecting member states, which would allow to motivate them more strongly to action which would provided for, in the period of good economic situation and stability, creating precautions allowing to prevent potential effects of recession and stagnation. They forgot about the basic canons of the economic theory of cyclic budget, which actually allow for resolving a budget closing with a deficit in the periods of bad economic situation, but only on condition of resolving budgets with a surplus balancing those deficits in the periods of good economic situation. The member states used the discretion in the sphere of this policy quite blithely and almost uncritically. This, in combination with the deep and long lasting crisis of the first decade of the $21^{\text {st }}$ century, resulted in a rapid growth in the public debt of the euro zone member states from $70 \%$ in 2005 to $90.6 \%$ in $2012,{ }^{3}$ as well as applying (in mid-2013) the procedure of excessive deficit to 20 of 27 member states of the community.

Despite noticing the problem relatively early and signaling the need for more insightful observation of the shape of public finances of particular states and

2 The common currency was introduced on 1 January 1999 for cashless transactions and on 1 January 2002 for cash transactions.

3 J. Stankiewicz, Doskonalenie procedury ograniczania nadmiernego deficytu jako instrument dyscypliny finansowej państw członkowskich Unii Europejskiej, in: A. Grynia (ed.), Reakcja na kryzys w krajach członkowskich Unii Europejskiej i perspektywy rozwoju, Vilnius 2012, p. 77 as well as European Central Bank, Statistics Pocket Book, April 2014, p. 46. 
Multiannual financial planning of the state in Poland compared with selected...

initiating a decisive disciplinary reaction acting against the undesirable phenomena of excessive budgetary deficit, it was not until 1997 that they recognized the need for introducing the Stability and Growth Pact into practice, ${ }^{4}$. Critical opinions on this act emphasizing the poor efficiency of its provisions of preventive nature formulated a few years after its introduction, were the basis of reforms implemented in 2005 and 2011. These provisions aimed to strengthen member states' discipline and their responsibility for the shape of public finances through introducing an obligation of obeying the medium-term budgetary objective.

The systematic infringement of standards resulting from the Stability Pact under the deep and lengthy economic crisis and failing to achieve the premises of the budgetary goal determined by the criteria of convergence, resulted in the EU member states (except the UK and the Czech Republic) signing the Treaty Establishing the European Stability Mechanism (commonly known as the Fiscal Compact). The Treaty could only come into force on 1 January 2013 if it had been ratified by at least 12 of the 17 member states of the euro zone. This was achieved in December 2012. The Treaty aims to implement the program of budgetary and economic partnership as well as annual budgetary plans consistent therewith, as well as monitoring its implementation according to the rules determined in the Treaty by the European Commission and the Council of the European Union. The end of the preamble states that granting financial aid under new programs within the framework of the European Mechanism of Stability would depend, from 1 March 2013 on, on the ratification of the Treaty by the contracting party as well as taking into consideration the date allowing for obeying the rules resulting there from within the whole cycle of the national budgetary mechanism. The Treaty is mandatory for the euro zone states and open to the states from beyond the zone. On 20 February 2013, the Sejm authorized the President of the Republic of Poland to ratify the agreement. Signed by the President of the RP the agreement came into force on 18 March 2013.

According to the Treaty the states under the derogation, which (like Poland) ratify the agreement, may be bound with all of its selected provisions included in Title III "Fiscal compact" and Title IV "Economic policy coordination and convergence". Ratification of the Treaty by a state under derogation means, on the other hand, a commitment to treating the requirements of the budgetary discipline established by the Treaty seriously. Monitoring the observation of the provisions of the Stability and Growth Pact and the Treaty by the European Commission and the Council of the European Union, makes the credibility of medium-term economic assumptions realistic and may become a realistic basis of implementing long-term financial planning. Beside irrefutable benefits the achievement of which may be encouraged by multi-annual financial planning, which would involve rationalization

See: J. Stankiewicz, Problemy racjonalizacji wydatków publicznych i wieloletniego planowania finansowego w aspekcie budżetu zadaniowego i wieloletnich planów finansowych w Polsce, in: E. Ruśkowski (ed.), System prawa finansowego, vol. II, Prawo finansowe sektora finansów publicznych, Warszawa 2010, p. 293 onwards. 
of the management of public resources, it allows for revealing explicit and implicit financial consequences of the realization of political commitments by the executivemanaging authorities, and, consequently, serves well to implement the principle of transparency of public finances.

The ways particular states achieve the medium-term budgetary goals are diversified, therefore, the concepts of multi-annual financial planning in particular states should be different too. Thus, characterizing the Polish practice of heading for implementing multi-annual financial planning at the level of state, this paper is focused on presenting the most important observations connected therewith against the experience of other states: France, which definitely may be counted among the countries with the richest practical experience in rationalization of public expenses, as well as Slovakia and Lithuania, which, along with Poland, were admitted to the EU in 2004. Moreover, Slovakia has been a member of the Eurozone for 5 years and therefore it remains under the obligation of maintaining a high level of permanent convergence, especially stability of public finances and a good shape of budgetary items, and Lithuania meets the conditions of admission to the euro zone and probably it will be admitted to the zone next year.

\section{Evolution of standards of the multi-annual financial plan of the state in Poland}

Poland's accession to the European Union in May 2004 may be recognized as the completion of the first stage of the political and economic transformation originated in 1989. The second stage may be defined as a stage of building a democratic state with social market economy, integrated with other states within the framework of the European Community. For the transformation it was necessary to implement democratic procedures of state functioning, to introduce market mechanisms into its economy as well as social changes consisting in society developing skills of adapting to the new rules of state functioning. The complexity of transformation processes, a downturn of economic development and a widening gap in material status of society, resulted in the process of making up losses in the standard of living in relation to developed countries, measured with a synthetic Human Development Index, shaping below the expectations formulated before. ${ }^{5}$ Hence, in the assessment of social acceptance of the effects of the changes, the revival of democratic state gains a strong approval while fulfillment of economic and social expectations in relation to the rates noted at its beginning, results in a wider polarization of views of both its strong supporters and its strong opponents.

$5 \quad \mathrm{HDI}$ : Human Developing Index taking into consideration statistics for 2012 prepared by the UN and classifying 187 countries ranks Poland in $39^{\text {th }}$ place in group I, to which very developed countries with the highest Human Developing Index are counted. In relation to the early 1990 s it is a considerable advancement (58 ${ }^{\text {th }}$ place in 1994) and stabilization of the position in the last decade ( $35^{\text {th }}$ place in 2003). 
The completion of the first stage of political and economic transformations meant the recognition that the Polish legal system, including the financial law system, had achieved at least a satisfactory level of convergence with European law. The change in status from "a state aspiring to join the community" into "a member-state of the community" evoked certain particular legal consequences manifested both in the rights and the responsibilities of the member state. From a time perspective it is possible to show the numerous and various complications that occurred in the process of harmonization of Polish financial law with Community law after the accession to the Community. Several complications occurred anyhow in the subsequent years, when shortages connected with discrepancies or incompatibilities of law and practice of its application with the European standards were gradually eliminated, often under strong pressure from the European authorities. ${ }^{6}$

Poland's joining, on 1 May 2004, the community of European states building their future on cooperation based on bonds of economic and military security, regional cooperation and jointly developed concepts of human development, implied a necessity of taking into consideration organizational connections between the national budget and the financial system of the European Union, which is based on multi-annual financial frameworks. This also meant an obligation to enhance the effectiveness of public finance management in a medium-term cycle. It is important to underscore that Poland, sufficiently in advance, managed to introduce a public debt threshold established by the Maastricht Treaty into the regulations of the binding Constitution along with prudential and remedial regulations establishing procedures in the case of exceeding the established public debt thresholds into the Act on Public Finances. It is also important to highlight the fact that our actions in the sphere of reforming public finances were implemented under very difficult and unfavorable external conditions, on which we had no influence. However, noticing and appreciating the impact of the presented determinants on the pace of the changes, one cannot ignore the fact that Poland from the moment of its accession to the European Union incessantly tackles the problem of exceeding budget deficit standards over the referential value and almost all the time is under the procedure of excessive deficit. Also other important convergence indices referring to the area of monetary policy (e.g. the criterion of price stability) or basic macroeconomic values are characterized by changeable dynamics. Thus, a potential future accession to the

6 C. Kosikowski, Prawo Unii Europejskiej w systemie polskiego prawa finansowego, Białystok 2010, p. 16. The Eurozone member states' evading to obey the requirements of financial security resulted in the weakening of the Eurozone and even a threat to its existence. It also weakened the arguments of opponents to EU interventionism in affairs of such a member state based on the European authorities taking control over part of sovereignty of the state in the budgetary sphere. This situation made the theoretical legal problem of the boundaries of interventionism and financial sovereignty of a state important and permanent, See. C. Kosikowski, Poziom granic i form interwencjonizmu Unii Europejskiej w dziedzinie waluty i finansów publicznych państw członkowskich, in: C. Kosikowski (ed.), Przyszłość Unii Europejskiej w świetle jej ustroju walutowego i finansowego, Białystok 2013, p. 101 onwards. 
monetary union must be determined by meeting the requirements of expedient and secure integration. ${ }^{7}$

A great number of expectations may result from the prolongation of the planning period. Depending on these expectations and the role ascribed to multiannual planning it should have an appropriate legal framework. Thus, we can implement the proposal, put forward for many years, of prolonging the planning period in such a way that the multi-annual plan will validly determine the state's obligations in basic social (human) and economic issues aiming at improvement of the social and material status of citizens, and annual plans will determine the way of achieving these goals. It is also possible to assume that prolonging the planning period is supposed to determine the way, the expectations, other than social (cultural, educational, civilization, improvement of material existence) ones, and not less important tasks of the state (defense, internal security and order, territorial cohesion of the state through reducing differences in the development potential on its territory, control over public debt of the state and preventing its unjustified growth threatening the financial security of the state etc.) are fulfilled. We can also assume that the reasons for prolonging the planning period are justified by development of modern knowledge and skills in forecasting and using electronic calculating technology allowing for a current analysis of the situation and potential correction of undesirable phenomena, and, through this, for rationalizing public finance management.

The proposal of prolonging the planning period is based foremost on the arguments emphasizing the fact that an important part of the tasks implemented with public funds are investments whose time of implementation exceeds (often significantly) the period of twelve consecutive months. Against these arguments other arguments can be presented. Undoubtedly, this prolongation of the budget period rationalizing guarantees of providing funds for financing the costs of the whole enterprise, is accompanied by the necessity to improve the methods of forecasting the scale of current expenses in the budget medium-term cycle as well as the need to develop instruments of reaction to unpredictable phenomena and current correction of deviations from the determined way. This concept does not change the present status quo between the legislative power and the executive-managing power in terms of their obligations and rights. It may be implemented either by prolonging the 12-month period or by establishing a longer period divided into subperiods. A multi-annual plan may define expectations and annual plans are to determine valid goals which must be achieved by the end of each subperiod to make the achievement of the final goal feasible. Finally, a multi-annual plan may be binding and may result in parameters necessary to achieve in subperiods included. If a dominating reason for prolonging the planning period is social (human) issues, due to historical traditions 
and an unquestionable substantial and political justification, such a solution requires rather an appropriate constitutional decision. If a dominating reason is to be technical aspects of financial planning such a condition does not seem indispensable. If, however, a consequence of the introduced changes would be a change of the relation between multi-annual planning and annual planning, appropriate changes in constitutional regulations seem inevitable.

A Multi-Annual Financial Plan of the State was introduced to the Polish financial planning practice by Article 106 para 2 of the Act of 27 August 2009 on Public Finances, ${ }^{8}$, according to the provisions of Article 122 para 1 of the Act of 27 August 2009. The regulations introducing changes into the Act on Public Finances ${ }^{9}$ were to be adopted by 31 July $2010 .{ }^{10}$ In the original version of the bill on public finances submitted to the Sejm on 20 October 2008 (Sejm paper no. 1181) its role was broadly outlined. It provided that "the Council of Ministers will adopt and present a multi-annual financial plan of the state to the Sejm, which will take a resolution thereon". ${ }^{11}$. It was also provided that the government would yearly update the plan by the date determined by the law and submit to the Sejm information on the state of its implementation during the debate on a report on the state budget implementation. The solution proposed would be, thus, from a formal point of view, correct, because, although actually the provisions of the Constitution claim that home and foreign policies are in the competences of the government, the binding regulations provide certain influence of the Sejm on determining directions of the state policies. Beside deciding on the shape of the budget act the Sejm is authorized to take problem resolutions in various areas, for example, those concerning economic and social (human) policies. Clear emphasis on social reasons could suggest an intention of vesting in this financial plan a role of a plan reflecting obligations of the state represented by the government to citizens, and even its potential transformation, in the future, into a multi-annual budget. Eventually, the government withdrew from the concept of confirming the plan with the Sejm resolution, reducing its rank to the role of a governmental auxiliary plan, which is only to be synchronized with other governmental plans. The change of the role of the plan did not change its substance significantly.

Another, after introducing the multi-annual financial plan of the state, innovative element of the reform included in the Act on Public Finances of 2009 was determining that the expenses of the multi-annual financial plan of the state would be laid out in a system which embraces the functions of the state or the planes of activities connected with implementing its tasks. Performance budgeting at the level of state was the first such a broad reform of budget planning aiming at rationalizing

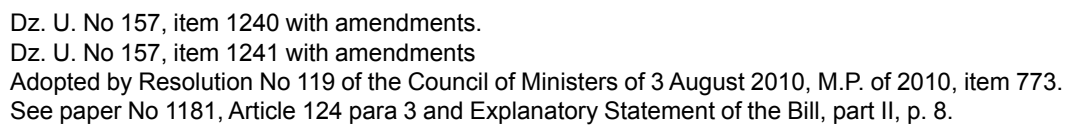


public expenses. The concept of the reform assumed the replacement (after gaining necessary experience) of the then appropriate method of preparing prospective projects of state budget on the basis of subjective division of public funds (division among disposers of parts of the budget), objective and functional division (division into goals and functions of the state). 22 functions of the state which determine the goals implemented by the state were identified. Within those functions 151 tasks were established, which included subtasks and actions enabling to achieve the task objectives. ${ }^{12}$. The most difficult challenge and necessary attribute of implementing the reform was to determine standards which would allow to control the state of implementation of the goals, as the essence of performance budgeting is planning and informing on the goals and effects of the use of public funds. The number of objectives and standards allowing for controlling the state of implementing particular goals was varied. The assumptions of the state finance reform were first determined in the Act of 8 December 2006 on the Amendment of the Act on Public Finance and some other laws. ${ }^{13}$ It was established that the explanatory statement for the budget bill would contain information on tasks, goals, expenses and standards. The practice of first experiments consisted in using this method for expenses of only some disposers and only selected parts of the budget. The exemptions of this type may be applicable at the stage of experiments exclusively. It was assumed that for the first time the holistic concept of performance budgeting would be applied for preparing a draft for the year 2013. So far the draft budget bill has been prepared with a traditional method and performance classification is applied in the multi-annual financial plan for research purposes.

It was assumed that the Multi-Annual Financial Plan would contain basic macroeconomic prognoses, such indices as: gross domestic product and its components listed in the law; rate of prices of goods and services; exchange rate, average gross wage in national economy, employment and unemployment rate, and current account balance. The income prognosis was prepared in compliance with requirements determined in Article 104 para 2 of the Act of Public Finances specifying: tax incomes divided into those from indirect taxes and direct taxes (indicating specific taxes); non-tax incomes (practically including mainly incomes collected by budgetary units: fees, fines and interests); dividends and payments from profits; payments of local government units; payments from the profits of the National Bank of Poland; duties and funds from the EU budget and non-refundable funds from the aid granted by the EFTA member states.

It was also decided that MAFP would be annually updated, and this updating would aim at introducing into the plan data confirmed by the budget act as values of the base year. The Act on Public Finances determined the date of updating, 
connected therewith, which depended on the day of the budget act promulgation. Simultaneously, the APF demonstrated that the reason for updating may also be securing the compliance of MAFP with the directions of the socio-economic policy and medium-term strategy of the country's development. In this case APF did not determine the date of correcting the prognosis. However, the Act of 6 December 2006 on the Rules of the Development Policy provided that the medium-term strategy of development would be updated at least once every four years, and the Council Regulation (EC) No. 1055/2005 of 27 June 2005 amending Regulation (EC) No. 1466/97 on the strengthening of the surveillance of budgetary positions and the surveillance and coordination of economic policies, also allowed for a revision of the medium-term budgetary objective of a member state in every case every four years, and also more often, any time it results from introducing a considerable structural reform. Noticing connections, strongly emphasized by the legislator, of MAFP with the budget law as well as the possibility of including this plan into the medium-term macroeconomic planning and thereby completing the missing system of substantive, financial and spatial planning as well as connections with the European regulations strengthening budgetary discipline to control its lasting, its considerable sensitivity to changes was underscored.

The amendment of APF of December 2010 is undoubtedly a consequence of Poland being placed under the procedure of excessive deficit and a recommendation referring to the way of its reduction. A rule was then established that a prognosis of expenditures in MAFP would be prepared for each budgetary year, according to the requirements defined by the expenditure disciplinary rule determined in Articles $112 \mathrm{a}-112 \mathrm{~b}$ of APF. These regulations were to reduce discretionary expenses of the state budget (flexible spending) and new fixed expenses, to the level compatible with the average annual index of prices of goods and services forecasted for the given year extended by 1 percentage point. The Act established categories of expenses exempted from the rule reducing spending (counting among them expenses on public debt service, expenses resulting from obligations assumed by Poland as regards implementing national and international agreements and binding regulations referring to pension and social welfare benefits). The legislator assumed that the spending disciplinary rule would be applied until the situation of public finances improve, which would manifest in lifting the procedure of excessive deficit for Poland. In practice, these regulations were applied while constructing the budget for 2011 and 2012. Unfavorable external conditions resulting from the current economic crisis as well as lengthy discussions between the government of the Republic of Poland and the European Commission in relation to the statistical methodology of presenting expenses of the pension reform in progress, resulted in the situation that Poland has until now been under the procedure of excessive deficit, and in this situation maintaining the spending disciplinary procedure was considered as burdened with negative consequences for macroeconomic stability. The amendment of 26 July 
2013 to the Act on Public Finances ${ }^{14}$ suspended its application in 2013, and the Act of 8 November 2013 on amending the Act on Public Finances and a number of other laws, ${ }^{15}$ the disciplinary spending rule was replaced with the stabilizing spending rule.

The deficiency of the lifted mechanism was the fact that some actions were taken only when certain prudential thresholds were exceeded. International experience has demonstrated that in the circumstances of slowdown in economic growth such a mechanism may mitigate the effects of this slowdown but at the same time may lead to a pro-cyclical intensification of it. It was concurrently stated that such a mechanism was devoid of automatic instruments which serve to prepare public finances for worse times. The Polish budgetary practice is an example of a situation where the permanent imbalance of public finances brought about exceeding the first prudential threshold, and its further duration put at risk exceeding another threshold. Instruments forcing certain behaviors provided by the mechanisms of prudential and remedial procedures, working procyclically, could tighten the fiscal policy, consequently leading to the risk of macroeconomic stability. The new formula is devoid of the signaled defects. Its introduction is supposed to achieve and maintain the medium-term budget objective determined by the Convergence Program. However, simultaneously, this amendment considerably changes the legislator's intentions in the scope of the relation between the budgetary act and the multi-annual plan, since it changes radically the content of the MAFP.

In accordance with the changes introduced at that beginning of 2014 MAFP consists of two parts:

1) the Convergence Program which establishes a medium-term prognosis of the economic situation for Poland, and

2) the state (government) tasks presented in the system which includes its main functions with the objectives and the degree of their implementation.

Actually it is difficult to justify the intentions of the legislator that imposed the obligation to include the Convergence Program into MAFP. The obligation of preparing the Program results from the Council Regulation 1466/97 of 7 July 1997 on the strengthening of the surveillance of budgetary positions and the surveillance and coordination of economic policies. ${ }^{16}$ Placing the Convergence Program in MAFP does not raise its rank. Neither does placing the plan beside the Convergence Program raise the rank of the Program, for we deal with a plan of a technical nature in relation to the budget act and is also confirmed by an instrument which is of government resolution rank. Moreover, MAFP is complemented with extra prognoses and documents determined in Article 103 para 2 of APF. Undoubtedly,

Dz.U. of 2013, item 938.

Dz.U. of 2013, item 1646

OJ EC L of 2 July 1997 with amendments, item 209. 
Multiannual financial planning of the state in Poland compared with selected...

adopting such a construction seems to underline the fundamental goal of such a legal solution - to achieve a stable shape of the whole Public Finance sector.

The November 2013 Amendment rescinded the institution of MAFP updating, and Article 103 of APF in its current valid wording decides on "preparing a plan for a budget year and three ,subsequent years." Thus the earlier concept of cyclic updating of its establishments was abandoned. Stabilizing the provisions of the plan, this solution is also of certain positive values. It may be transformed into a multiannual plan with binding spending parameters for particular changes but a solid and clear legal construction needs to be established to do so. The government does not declare a will to introduce such a solution. The only thing we may expect is the rules of annual planning annually determined with a budget note will shape permanent practice of multi-annual financial planning.

\section{Legal solutions of selected states and their practice in applying multiannual financial planning}

France has enormous experience in introducing the methods of rationalization public spending. A basic instrument of French theoretical reflections and practical experiences considerably affecting the current policy was the RBC method applied there for almost 20 years (1968-85). While searching for methods of rationalization of spending public funds it was observed (following the American concept PPBS), that modern socio-economic circumstances require from the state implementing medium-term and long-term programs of achieving public objectives. A financial counterpart of programs containing characteristics of economic and social effects of their implementation were budgets of programs grouping needs for the funds necessary for their implementation, based on an analysis of estimated costs and expected profits. In contrast with fragmentary experiences and experiments applied in different states, in France, budgets of programs were developed in all ministries for a few years.

The principle of annuality of budget is very strongly embedded in the French law system. It found its reflection already in the Constitution of 1791 and then in the royal decree of 1822 on adopting "an annual act on finances" as regards accountancy and justifying public spendings, in the decree on budget law of 1862 (being the first so comprehensive quasi-codification of budgetary law of a European state), in which a definition of budget was formulated (considered a classical one until now) and finally in the organic ordinance of 1959 binding until 2001. Although as early as the inter-war period attempts were taken to prolong the annual frameworks of financial planning through introduction of the so-called prolonged budgets (budgets whose validity was prolonged for another year; e.g. the budget for 1923 was prolonged over 1924) and biennial budgets (a budget adopted once in one voting for the next 
subsequent years, for example the budget for the years 1934-35), it is important to underscore that in the French academic doctrine ${ }^{17}$ the principle of annuality of budget is unanimously named in the first place among traditional (classical) rules of budgetary economy. Referring to the problem of multi-annual financial planning in the French budgetary law, the outstanding expert in these issues, M. Bouvier, states that at the moment we deal with the position according to which formally multiannuality is an exception to the rule of annuality. ${ }^{18}$. However, several internal and external determinants affect that. The main external element being an impulse for introducing multi-annual financial planning, is the EU imposing an obligation to develop a multi-annual concept of public funds to establish the way to achieve financial stability. Since 2009, France has been under the procedure of excessive deficit and its hitherto efforts to achieve stability has been regarded insufficient.

The Organic Law of $2001{ }^{19}$ confirms the validity of annuality as one of the main principles of the French budgetary law. This act does not take into consideration solutions on a multi-annual pilot testing. Assessing the situation, M. Bouvier pointed out that as a consequence of such a regulation "a specific inaccuracy occurred as a result of insufficient precision of the term program referring to the period for which it is developed". ${ }^{20}$ It was only the amendment to the Constitution of 23 July 2008 (that introduced multi-annual programming repealing the regulations, arousing objections for several years and deciding on non-binding nature of the laws on programs) is regarded as an important step materializing multi-annual budget programming. The Constitution provides that multi-annual directions of public finances are defined in programming laws, whose objective is to balance the accounts of public administration. The new version of the Constitution points at the goal of implementing programming laws, which is balancing public accounts, and introduces a definition of multi-annual programming of the whole sector of public finances.

The Act of 23 July 2008, which amended the Constitution, enabled entering into force a new category of laws: laws on multi-annual public finance programming. It is emphasized that in the light of the rules of French law organization, acts on multiannual public finance programming have no status of organic laws (are not financial or budgetary laws) but ordinary laws. Owing to this, the assumed solution does not infringe the principle of annuality remaining in compliance with the position of the Constitution and the doctrine. It enabled to adopt the multi-annual financial

P. Lalumière (1973); Ch. Bigaut (1995); P.M. Gaudemet, J. Molinier (1997); J. Mehkhantar (2003).

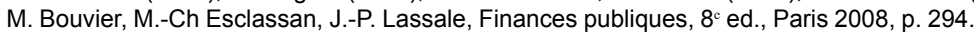

In the literature it is referred to as LOLF (fr. loi organique relative aux loi de finances).

M. Bouvier, Konstytucjonalizacja wieloletniego programowania finansów publicznych we Francji, in: E. Ruśkowski (ed.), Instrumenty nowego zarządzania finansami publicznymi w wybranych krajach Unii Europejskiej, Białystok 2011, p. 33 onwards. 
Multiannual financial planning of the state in Poland compared with selected...

plan for the period 2009-11, ${ }^{21}$ which neither infringes nor negates the rule of budget annuality. Multi-annual financial programs are not (as President Sarkozy put it) "multi-annual budgets either, because they include only spending limits. On the other hand, as discussed in the National Assembly and the Senate, annual financial (budgetary) laws (which include both expenses and incomes) are the only ones with binding force and with their spending aspect are inherent in the framework of three years' programming.

The first multi-annual financial program established a general limit of expenses for three years and could not be changed but modified only, if the initially assumed rate of inflation increases (in the case of a fall of inflation rate no modification was provided). It would also establish limits for particular functions, for funds transferred to local government units and for EU. For the first two years of programming they were definite values, for the third year they could be modified, if the general spending limit was not exceeded. Then the allocation of expenses into programs was established. It remained intact in the first year of programming and as so determined an amount was taken into consideration in the budget bill. On the other hand, it could be modified in subsequent years. The third year was a basis for the development of the next multi-annual program. Two consecutive acts on programming included three-year sections (respectively: the years 2009-2011 and 2012-2014). After the Organic Law of 18 December 2012 on Programming and Management of Public Finances entered into force, the Act on Programming for the years 2012-2017 was adopted (thereby repealing the law which was to be valid until 2014).

The Republic of Slovakia and the Republic of Lithuania are states which share the date of accession to the European Union with Poland. Before this date all aforementioned states were to a high degree similar in organization of budgetary economy as to annuality and multi-annuality of the financial management of public funds. We can say that the main source of law of these states refer similarly to the basic organizational questions of budgetary systems, as well as that a certain common thread binding the organizational solutions of these states is the same requirements resulting from the obligation of preparing stability programs (Eurozone states) as well as convergence programs (states under derogation). However, in specific issues we can point out several crucial differences.

First of all, it is important to highlight the fact that the Republic of Slovakia has belonged to the euro zone since 1 January 2009, whereas the Republic of Lithuania did take efforts to introduce the common currency euro, which turned out unsuccessful. The failure resulted from the fact that inflation rate was exceeded. In the early years of the economic crisis the inflation grew rapidly to such extent that in 2009 the European Commission recommended, and the Council of the EU on 7 July

21 During the first Council for Modernization of Public Policies the then President Nicolas Sarkozy stated: „....we establish, for the period 2009-11, a multi-annual budget, coherent with the directions of our public finances...", quotation after M. Bouvier, op. cit., p. 33 onwards. 
2009 made a decision and applied the procedure of excessive deficit to Lithuania and issued recommendations of its removal by 2012 . This requirement was fulfilled and on 21 June 2013 the procedure of exceeding deficit was closed for the Republic of Lithuania. Currently Lithuania's accession to the euro zone is assumed for the year 2015.22

The Constitution of Slovakia of 1 September 1992 r.efers to the problems of public finances to a minor extent. In contrast to many modern constitutions it did not dedicate a separate chapter to public finances. The Constitution does not refer to the issues of annuality or multi-annuality at all, merely stating that the state budget is approved of with an act of law.

Contrary to that, the Constitution of the Republic of Lithuania, enacted in the referendum on 25 October 1992, in Chapter XI on Finances and State Budget stipulates the principle of annuality of the state budget very clearly and does not provide an institution of financial planning. On 28 June 2012 the Seimas of Lithuania also ratified the Fiscal Compact, which admittedly will be fully applicable to the Lithuanian state having fulfilled certain conditions. However, the fact of ratifying this act by a country under derogation, resulting in binding itself with selected provisions of Title III Fiscal Compact and Title IV Economic Policy Coordination and Convergence (like in the case of Poland), is a very clear signal of its readiness to subordinate to the requirements of budgetary discipline and building the system of credibility of medium-term economic assumptions.

In spite of the clear exposure of the principle of annuality, particular states introduced original solutions even before their accession to the EU, which, on the one hand, may be treated as an exception to the rule of budget annuality serving to prolong the budget period and thereby rationalizing public spending, and on the other, as an exception to the rule of annuality understood as permission to derogate from this rule. In this sense in the practices of the two states we can talk about such derogations the effect of which is heading towards medium-term planning with simultaneous exposure of the rule of annuality. Under Act No.303 on budgetary rules, the Slovakian legislation introduced three-year budgets i.e. a binding budget for one year and non-binding budgets for two subsequent years. As a rule, they were held in acts of 2004 addressed to the government administration as well as to local government units, and then confirmed and extended by Act No. 493 of 2011. This law stipulates that the National Council adopts an annual budget bill (with certain exceptions), apart from a three-year budget of public administration approved by the government and submitted to the parliament for informative purposes only. Besides, it is important that the three-year budget is appended with reports on implementing the budgets for previous years, thereby making a five-year budgetary cycle a subject 
Multiannual financial planning of the state in Poland compared with selected...

of analysis. ${ }^{23}$ In the Republic of Lithuania the Seimas approves the programmed national budget indices for the period of three years. The act of approval is in the form of a resolution of the Seimas of quite a general nature which determines only total amounts of budgetary incomes and expenses provided for particular years, even without division into a budget of the state and budgets of municipalities. The act of approval binds neither the government nor the Seimas, because, without any legal and actual limits and without consequences, the following year amounts may be completely different. In spite of this it is not possible to definitely state that they did not actually affect the shape of the annual budget of the state. Before 1 January 2014, apart from some resolutions of the Seimas on three-year indices of the national budget, there were legal constructions (applied at the stage of implementing the budget) which "prolonged" its annuality. E. Ruśkowski defines them as technical or declaratory constructions. There were also practical connections between the annual state budget and various documents, including those of the nature of programs (also programs indirectly connected with public finances and concerning, for instance, achieving various macroeconomic objectives).

Bearing in mind that the budgetary system of Lithuania in many aspects fails to meet the standards determined by the Directive of the Council of 8 November 2011 on requirements for budgetary frameworks of the Member States, the Lithuanian government adopted in November 2012 an extensive and specific program of implementing the provisions of this directive. Among the decisions taken in this program (which entered into force in 2014) there are also the ones which essentially differ from those applied in other states (like in Poland). For instance, on the basis of government programs the Seimas of the Republic of Lithuania approves projects of three-year budget indices. Projects of state budget (and budgets of municipalities) may not comply with the forecast indices approved for three years. However, in such a situation the government is obliged to submit a written explanation to the Seimas on how new priorities of economic and social (human) policies are reflected in these changes. The program does not establish the form in which the Seimas takes its standpoint towards the explanation presented (the whole spectrum of options is possible: from that accepting acknowledgement, through the demand of completing the explanations, and even their rejection). In Slovakia, the Constitutional Act of 2011 on Budgetary Accountability appoints an independent organ for monitoring and evaluation of economic development and assessment of implementing the principles of budgetary accountability. This agency will, among others, be vested with competences such as preparing and publishing reports on long-term stability of public finances of the state.

23 E. Ruśkowski, Roczność i wieloletniość w finansach publicznych Republiki Słowacji, duplicated typescript, a study prepared within the framework of the research project „Roczność i wieloletniość w finansach publicznych Republiki Słowacji, financed by NCN (UMO-2011/01/B/HS5/03357). 


\section{Conclusions}

Fiscal rules are one of the characteristic instruments of the reform of management of public funds in European states in the face of financial crisis manifesting itself by growth in budget deficit and public debt. Apart from transnational quantity rules, which had to be fulfilled by the states aspiring to accession to the EU, new rules have been introduced that are binding on the euro zone member states aiming at achieving a medium-term budgetary objective. Moreover, several various national rules appeared which were established by particular states, aiming at combating undesirable phenomena. Besides the existent fiscal rules concerning the desirable level of budgetary deficit and public debt in relation to GDP, others appeared such as: appointing independent fiscal institutions, obligation of establishing medium-term budgetary frameworks and current monitoring of the maintenance on the established path of implementation, as well as introducing budget procedures guarding budgetary discipline. ${ }^{24}$ Within the framework of the reforms introduced as a result of the rapid deterioration of the economic situation in 2008, EU member states foremost increase the range of use and restrictiveness of the institutional solutions of the fiscal policy. The observations conducted prove that among four most important areas of reforms of public finances as well as the use of institutional restrictive solutions, i.e. according to rules, institutions, procedures and medium-term financial planning, according to the date of the European Commission for 2009, the most frequently applied methods are changes of budgetary procedures as well as changes of fiscal rules. ${ }^{25}$ Among the countries under scrutiny, Poland and Slovakia have decided to introduce spending rules. All the states apply in their legal solutions the rule of annuality of budget modified in practice with introducing elements of multi-annual financial planning.

Also, earlier experiences have undoubtedly had an impact on the selection of the method to implement the concept of the reform. One of the essential elements of success is to adopt a high legal rank of the agreed rule through its record in the Constitution or in a Law on Public Finances, which will confirm its serious and longterm nature. One of a few reasons which contributed to the failure of introducing the method of rationalization of budgetary choices of the Government Centre for Security in France, was a weak connection of the method with the budgetary procedures and lack of a strong political impulse comparable with the one which supported the method Planning, Programming and Budgeting System (PPBS) in the United States ${ }^{26}$. This mistake was not repeated in 2000 when the reform was 2012, vol. 10, No. 3, p. 47. Ibidem, p. 54.

U.K. Zawadzka-Pąk, Etapy wdrażania współczesnego budżetu zadaniowego we Francji, in: E. Ruśkowski (ed.), Prawne problemy konstrukcji i funkcjonowania budżetu zadaniowego we Francji. Wnioski dla Polski, Białystok 2010, p. 54. 
introduced in France. This reform was carried out with a dominant role and support from the part of the Parliament, with an appropriate organizational framework and the highest rank of legal regulation. Its director and author was the Parliament and not the central administration seeking its favors. ${ }^{27}$ The complete lack of political support for the reforms of public finances in Poland, the lack of legal grounds in the sources of law of the highest hierarchy, no clear definition of the goals of multi-annual planning of the state finances, does not give a fair promise for the Polish reform of public finances. Its weak shape manifests itself in the fact of several concepts of changing the role of this plan, which less frequently is perceived as one of the principal instruments of the reform of the state finances, and more and more often is reduced to the role of a technical government plan, which is to serve to improve budget planning.

Transnational fiscal rules have an essential influence on adopting certain national rules. Particular states, selecting their way of stabilization and strengthening the shape of public finances and their rationalization, base their choices on their hitherto experience. Observation of the hitherto practice demonstrates that the established objectives will be achieved in particular states at a different pace and along different paths.

27 E. Ruśkowski, in: E. Ruśkowski (ed.), Prawne problemy konstrukcji..., p. 100. 


\section{WIELOLETNIE PLANOWANIE FINANSOWE PAŃSTWA W POLSCE NA TLE WYBRANYCH KRAJÓW EUROPEJSKICH}

Wprowadzenie wieloletniego planowania finansowego oraz przygotowania do wprowadzenia metody planowania zadaniowego to najbardziej eksponowane elementy reformy finansów publicznych wprowadzone ustawą o finansach publicznych z 2009 r. Determinanty wprowadzania tych rozwiązań mają charakter wewnętrzny i zewnętrzny. Przestrzeganie średniookresowego celu budżetowego i wymogów dyscypliny budżetowej ustalonych prawem europejskim wymusza stosowanie metod racjonalizowania gospodarowania środkami publicznymi. Wieloletnie planowanie finansowe sprzyja racjonalizowaniu gospodarowania tymi środkami, czyni praktykę wydatkowania tych środków bardziej transparentną, ujawnia wyraźne i ukryte konsekwencje finansowe realizacji politycznych zobowiązań. Wyraźne określenie zamierzonych celów pozwala na dobór najlepszej metody prowadzącej do ich osiągnięcia. Kolejne nowelizacje ustawy o finansach publicznych zmieniają te cele i standardy Wieloletniego Planu Finansowego Państwa. W opracowaniu przedstawiono kierunki tych zmian oraz instrumenty, które maja służyć ich realizacji w Polsce, na tle rozwiązań innych państw - Francji, która ma zdecydowanie większe doświadczenie i realizuje w pełni koncepcje planowania wieloletniego oraz stosuje metodę budżetowania zadaniowego oraz Słowacji i Litwy, które podobnie jak Polska zostały przyjęte do UE.

Słowa kluczowe: Wieloletni Plan Finansowy Państwa, roczność budżetu, ustawa budżetowa, reguły fiskalne, budżetowanie zadaniowe

Keywords: Multi-Annual Financial Plan of the State, budget annuality, budget act, medium-fiscal rules, performance budgeting 